\title{
Whole-Earth agency proposed
}

\author{
Two major US science agencies should merge to streamline research on problems such as \\ climate change, say former agency heads. Anna Barnett reports.
}

$\mathrm{n}$ response to looming environmental challenges such as climate change, a group of former senior federal officials has called for the next US president to create a new Earth sciences body by merging two huge existing agencies.

The proposal, published in the 4 July issue of Science, would see the National Oceanic and Atmospheric Administration (NOAA) and the US Geological Survey (USGS) unite to form a single institution with the suggested title of Earth Systems Science Agency (ESSA). NOAA, headquartered in Washington DC and in charge of ocean and air research, is separated from USGS, which covers just about everything else comprising the Earth system, from biology to energy and mineral resources, and has regional offices throughout the United States.

\section{"We should be looking to the future and designing our scientific institutions around the challenges we face." \\ Richard Anthes}

Fragmented Earth science programs housed within much larger government departments are missing opportunities for collaboration, says Mark Schaefer, former acting director of USGS and lead author of the proposal. Closely aligned research groups "should be working side by side," he argues." Related "research programs should be planned together, and their budgets should be developed together," he adds.

This is the latest of many proposals to reorganize federal government science in the United States, says USGS ecologist Glenn Guntenspergen, who wonders whether a merger between these two agencies is the right place to draw the line. "The question would be to ask if it would make doing our science easier," he says. "I certainly don't have an answer to that."

\section{FRESH APPROACH}

With climate change, sea-level rise, freshwater shortages and loss of biodiversity on its docket, the proposed agency would be expected to deliver comprehensive research on these and other Earth processes such as natural disasters and extreme weather, while also funding outside investigators and even exploring game-changing green technologies.

Supporters of the idea say erasing the bureaucratic divide could give a synergistic boost to Earth-system research. Separating NOAA from USGS "is not how you'd set it up if you were starting fresh," says Richard Anthes, president of the University Corporation for Atmospheric Research in Boulder, Colorado. "We should be looking to the future and designing our scientific institutions around the challenges we face."

But others argue that ESSA might be a solution to the wrong problem, the real issue being research financing. "The main issue is not bureaucratic organisation, but the lack of interest at any level in funding interagency or interdisciplinary programs," says
Gavin Schmidt, a climate modeller at the NASA Goddard Institute for Space Studies in New York. He says merging the agencies would help only if it meant more funds for cross-cutting research, and not just "changing the names on the buildings".

\section{CRUCIAL TIMING}

The present surge of public concern over global changes - echoing

the national environmental movement that bore the

Environmental Protection Agency in 1970 - makes the timing of the ESSA proposal suggestive. Says Anthes: "If not now, when? It can be done at the beginning of a new administration easier than at any other time."

With 25 per cent of the proposed agency's budget earmarked for academic and nonprofit research outside the agency, Schaefer hopes reshuffling would alter anaemic support for American Earth science. In comparison, NOAA and USGS now give out only a few per cent of their budgets as grants.

And with the reordering of priorities after the 2008 election, says Schaefer, "This is an opportunity ... to be able to make the case for more funding, and turn this into a truly world-class institution."

Published online: 17 July 2008

doi:10.1038/climate.2008.74

Anna Barnett is assistant editor and copy editor of Nature Reports Climate Change. 